\title{
Religion, Religious Tradition, and Nationalism: Jewish Revival in Poland and 'Religious Heritage" in Québec
}

\author{
GENEVIÈVE ZUBRZYCKI \\ Department of Sociology \\ University of Michigan
}

\begin{abstract}
This article uses and develops Martin Riesebrodt's distinction between religion and religious tradition to shed light on the making of various articulations of religious identities and political projects. Based on extensive research on the Polish and Québécois cases, I show how social and state actors in these societies reactivate past religious traditions to respond to current social transformations and articulate societal projects and advance political agendas in the present. In both cases, religion and religious tradition are juxtaposed to articulate new national identities or fortify older ones, and to respond more specifically to the challenges posed by "pluralism." I suggest that sociologists who work at the intersection of religion and politics can contribute to our understanding of the various registers through which religion, religious action, and religious tradition are rendered meaningful to social actors, used for different goals (religious and not) and transformed in the process.
\end{abstract}

Keywords: Nationalism, Poland, Québec, Riesebrodt, religious action, religious tradition.

\section{INTRODUCTION: DeFinitions AND QUeSTIONS}

"Religious" actions, for Martin Riesebrodt, are "those whose meaning is defined by their reference to personal or impersonal superhuman powers" (2010:76). "Religion" is a complex of religious practices based on the premise of the existence of superhuman powers that offer the promise of salvation. "Religion" and "religiousness"—an individual's subjective appropriation of a religion-are notably different from the broader category of "religious tradition," "the historical continuity of systems of symbols" (Riesebrodt 2010:xii) that evolved out of them, and from which empirical religions draw in their repertory. "Religious tradition" may refer to classifications of discourses and practices in terms of theological or symbolic continuity, or to the empirical category of practices understood as having "always already" been performed in that way (Riesebrodt 2010:77). It is more comprehensive in terms of practice and also often includes ethnicity or culture (Riesebrodt 2010:14), though "religion" may, in practice be derived from various religious traditions, and in that sense be an expansion or elaboration on them. ${ }^{1}$ This distinction between religion, religious action, and religious tradition is immensely important and

Acknowledgments: Research for this article was generously funded by faculty grants from the University of Michigan's Office of the Vice President for Research, the University of Michigan's Rackham Graduate School, and the University of Michigan's College of Literature, Science and the Arts, as well as from the American Sociological Association's Fund for the Advancement of the Discipline. I'm grateful to Elizabeth Young for her research assistance on the Québec case. Thanks to the participants in the symposium honoring the scholarship of Martin Riesebrodt at the University of Chicago's Divinity School in January 2011 and especially to Malika Zeghal, Bruce Lincoln, and Wendy Doniger. Finally, I'm especially thankful to Mary Ellen Konieczny, Kelly Chong, Loren Lyberger, and Paul Johnson for their incisive and constructive comments on earlier drafts.

Correspondence should be addressed to Geneviève Zubrzycki, Department of Sociology, University of Michigan, 500 South State Street, Ann Arbor, MI 48109.E-mail: genez@umich.edu

${ }^{1}$ For Riesebrodt, religion can be analytically distinguished from culture, in so far as religious practice is distinguished from religious tradition (2009:13). 
useful, yet Riesebrodt mostly deploys religious tradition in relation to his interest in religion per se, and what he takes as the proper focus of the sociology of religion, namely, "individuals and group intercourse with superhuman powers" (Riesebrodt 2010:79).

Scholars of nationalism are less concerned with the meaning of religion as a system of practices related to belief in superhuman power than in how such beliefs and practices are yoked to issues of authority, political legitimacy, and social contest. If religion can be converted into political capital, religious tradition-as a set of discourses, symbols, practices, and material resources-is already thoroughly political. In many cases, in fact, it is difficult if not impossible to separate "religious" acts from political ones. It is religion mostly invoked as a tradition that defines "who we are," a phrase blending religious and political claims and sentiments into a single figure. Indeed, such combinative force is arguably the function of tradition, "who we are," rendering religious and national identities inseparable and, through this ideological doubling, as impenetrable as a fortress.

A focus on political identities should not be conflated with a Durkheimian perspective in which form prevails over content to the extent that, as Riesebrodt pointedly notes, "barbecues with guitar music, soccer games, shopping in supermarket or art exhibitions" are considered to be religious phenomena (2010:xi). Riesebrodt, like others ranging from E. B. Tylor in the 19th century to Jonathan Smith (1998) and Bruce Lincoln (2003) in the contemporary moment, argues that such a caricatured expansion of the concept of religion drains it of any analytical purchase. Yet if his definition of religion offers analytical clarity, religious tradition remains unclear.

In this article, I expand on the distinction between religion and religious tradition, but focus especially on the important but as-yet underdeveloped concept of the latter, to shed light on the making of competing articulations of political and religious identities. I explore how Riesebrodt's theory of religion can help us specify the roles religion and religious tradition play in the making of modern societies and their political structures, and show how sociologists who work on the intersection of religion and politics can contribute to our understanding of the various registers through which religion, religious action, and religious tradition are rendered meaningful to social actors, used for different goals (religious and not), and transformed in the process. Riesebrodt argues, at least implicitly, that religious tradition is an expansion of religion as it comes to influence and become part of other domains of human action. Religious tradition and religion happen in a relation of continuity. I will argue, by contrast, that religious tradition and religion intersect variously depending on the political project, but can also work at cross-purposes. I compare a case of one religious tradition being promoted to tame another religious tradition (Poland) and a case of religious tradition being invoked to tame particular religious aspirations (Québec).

\section{Presentation of the Cases}

In this article I focus on Poland and Québec, ${ }^{2}$ juxtaposing them to construct, following Riesebrodt's method (1990), historically and structurally limited hypotheses about the relationship between religion, religious tradition, and national identity. In both societies, Catholicism was historically central in defining ethnonational identities against their respective neighbors/colonial powers (Anglo-Protestants for Québec; Protestant Germans, Orthodox Russians, and, later, atheist Soviets for Poland), and in both cases the Catholic Church played a central role in civil society (Balthazar 1986; Bouchard 1999; Dumont 1986; Eid 1978; Ferretti 1999; Morawska 1984; Kłoczowski 2000; Zubrzycki 2006). In both instances, in short, Catholicism and the Catholic

\footnotetext{
${ }^{2}$ My analysis of the cases is based on years of archival and ethnographic research at both field sites. I discuss here findings that I have presented in minute detail elsewhere (Zubrzycki 2001, 2004, 2006, 2010, 2011, in press) in order to highlight bright insights and blind spots in Riesebrodt's theory for social scientists working on religion as a historically constituted politically salient category.
} 
Church provided symbolic, material, and institutional resources through which national identity was constructed and through which political projects could be articulated. In both cases, moreover, moments of political transition and episodes of state (re)formation inaugurated a redefinition of collective identity that countered ethnoreligious principles with civic-secular ones (Breton 1988; Dumont 1993; Frenette 1998; Lamont and Bail 2005; Taylor 2007; Thériault 1999; Zubrzycki 2001, 2006, in press).

It is therefore Catholicism as it was historically reshaped from religion to religious tradition that is at the center of the questions I pose. I selected two contemporary phenomena in which social and state actors reactivate past religious traditions to respond to social transformations, articulate societal projects, and advance political agendas in the present. In both cases, I show, religion and religious tradition are juxtaposed to articulate new national identities or fortify older ones, and to respond more specifically to the challenges posed by "pluralism."

In Poland, the crisis of pluralism is one of absence: How can Poland, one of the most ethnically, denominationally, and religiously homogenous nation-states in the world, counter the empirical absence of a plurality of ethnic and racial minorities religious groups to meet the normative goals of pluralism and multiculturalism, now enshrined as core values of modern polities? How can it articulate and project an image other than that of Polonia semper Fidelis, both at home and abroad? I will show how non-Jewish Poles' passion for Jewish culture and the support for the revival of Judaism is partly a strategy from the center and the left to resist the ethnoCatholic version of Polishness the Catholic right wants to impose, and serves to build pluralism in a homogeneous nation-state. Here, then, the revival of one religious tradition (Jewishness) and religion (Judaism) is supported to offer a counterweight to the dominant religious tradition in that society (Catholicism).

In Québec, the crisis of pluralism is one of presence and poses many of the usual challenges modern self-avowed secular societies face with the immigration of populations who are not only "denominationally Other," but who also are markedly more religious in their world outlook and in the exercise of their daily activities than members of the host society. The managing of pluralism in Québec occurs, however, in a liberal society that not only rejected Catholicism as a religion, as an institution and as a key feature of its national identity in the 1960s, but where the group, Québécois of French Canadian descent, is insecure vis-à-vis its own continuity as a people. The Québécois' double status—majority within Québec, minority within Canada—makes them especially eager to defend their central position within Québec. They do so by ensuring the use of French in the public sphere but also, more recently, by tapping onto their religious tradition as a way to assert their dominance in a public sphere increasingly colored by religious others. In this case, religious tradition (Catholicism) is resurrected as a secular "cultural heritage" to counteract the religion of Others (Islam, Orthodox Judaism, Sikhism).

The analysis of these two cases will reveal different but related dynamics-how religious traditions are used to create or constrain pluralism and articulate extra-religious identities. Yet I argue that in both cases, religious tradition is sacrosanct in its own right. In the end, the analysis of these two cases offers an expansion of Riesebrodt's concept of religious tradition in relation to processes of secularization and (re)sacralization.

\section{Reviving the "Jew” to Build "Real” Pluralism"}

What does pluralism mean in a society whose citizens are 96 percent ethnically Polish and 95 percent Catholic? ${ }^{4}$ What is religious pluralism in a society where 93 percent of citizens

\footnotetext{
${ }^{3}$ The quotation marks indicate the symbolic and discursive nature of the categories.

${ }^{4}$ According to the 2002 census data (Polish Census Data 2002). It goes without saying that ethnic, national, and religious identities are constructed and that such bounded categories are no more real or objective than others that are deemed
} 
declare that they believe in God, and 70 percent participate in religious services at least once a month (Centrum Badania Opinii Spolecznej 2009) ${ }^{5}$ If one were to look only at these statistics, Poland would appear to be a monocultural society where the issue of religious pluralism simply does not exist. And yet, the issue of pluralism has been one of the most contentious ones of the postcommunist and post-EU periods. To understand this, we must take into account the processes through which that nation's current demographic makeup was achieved and naturalized. For most of its history, Poland was significantly diverse, populated by people belonging to different ethnic, linguistic, and religious communities. With the advent of World War II, the Holocaust, and the postwar redrawing of Poland's borders, this changed dramatically: while ethnic Poles, on the eve of the war, constituted approximately 65 percent of the Second Republic's population, by 1946 they accounted for about 95 percent of the People's Republic. The population's religious makeup was also dramatically changed by World War II and its aftermath: in the 1931 census, Catholics comprised 65 percent of Poland's population; by 1946 the proportion of Catholics had increased to 96 percent of the population within the new borders (Michowicz 1988; Tomaszewski 1993).

Poland's current ethnic and religious homogeneity is therefore the byproduct of relatively recent historical events and political processes. But this radically new reality was successfully naturalized and normalized in the postwar period. In its attempt to legitimate its political domination over a resistant population, the communist party state emphasized that it was securing an ethnonational state, and worked diligently at erasing even the memory of diversity by repressing the multiethnic and multireligious past of the First and Second Republics. The postwar demographic makeup was also normalized by the Catholic Church, which gained considerably from being able to portray itself as the authentic "nation's keeper." Combined, these processes further tightened the association between Polishness and Catholicism (Zubrzycki 2006).

If pluralism was politically sensitive under state socialism, systemic transformations since 1989 have not resolved the issue. The mere idea of pluralism has been vigorously contested in various public debates punctuating the last two decades. One of these key debates concerned the nature of the newly independent and democratic state: the Catholic right and the official hierarchy of the Catholic Church emphasized the "objective" homogeneity of Poland's population and pointed to a concrete set of Christian values to be protected in a confessional state; public intellectuals and politicians on the left, the center, and liberal Catholics stressed the nation's ideological heterogeneity and argued that since Catholicism is only one among many competing or overlapping value systems, the state should be confessionally neutral.

In contemporary Poland, therefore, the very idea of pluralism is contested, as the conservatives and the far right insist that the country is monolithically defined from a core set of values. Many wield Poland's demographic statistics ("95 percent Catholic," "98 percent believers") to legally enforce their vision of Poland. Such statistics were used to support and justify the inclusion of an invocatio Dei in the 1997 Constitution (Zubrzycki 2001), to ban gay pride parades in Warsaw, or to maintain strict legislation on abortion. If under communism religious discourse

subjective. I do not take demographic homogeneity as a fact but as a social construction sometimes invoked for ideological and political purposes.

${ }^{5}$ These trends hold even among the young and the educated. Only 10 percent of Poles between the ages of 18 and 24 declare not participating at all in religious services of any kind, and about 80 percent of Poles with higher education consider themselves religious ("osoba wierząca"), half declaring participation in religious services at least once a week (Centrum Badania Opinii Spolecznej 2009). Poland thus remains surprisingly religious since the fall of communism, while one may have anticipated significant transformations in that sphere. But as I show in this article and elsewhere (Zubrzycki 2001, 2004, 2006), while survey data are helpful to paint the broad picture of Poland's religious landscape, one needs to turn to qualitative analysis to capture the subtle (and not so subtle) transformations that have taken place in the last two decades. 
was used to advocate the building of an open society, since the fall of communism it has been used primarily to shrink the symbolic boundaries of the nation by excluding those considered unworthy of full membership_-"Jews," secularists, civic nationalists, "bad Catholics," and sexual minorities.

This points to an interesting paradox. Whereas such ideological forms of exclusion are typical of places where the nation is understood in civic terms, and where, therefore, one's national identity - at least ideally - is determined by his or her adhesion to the principles of the social contract - whatever its terms - it ill-befits a place where the nation is primarily understood in ethnic terms, following the German, romantic model of nationhood. ${ }^{6}$ In line with this conception, national identity can neither be chosen nor escaped; it is transmitted through birth, "flowing through one's veins," constitutive of an imagined primordial self. How is it possible, given this dominant understanding of national identity, to exclude ethnic nationals from the nation? How can the conservative Catholic right insist on the primordial, blood-based character of Polishness while simultaneously excluding some members on ideological-political grounds? ${ }^{7}$ How is the tension between these two modes of social closure, one based on blood and culture, the other based on ideological orientations and political bonds, reconciled? In the Polish case, "ideological incorrectness" is ethnicized such that liberal intellectuals advocating a civic and secular Poland are turned into "Jews." But why Jews instead of Ukrainians or Germans? Because Communism, Western-style capitalism, liberalism, and cosmopolitanism are specifically associated with Jewishness; and also because Jewishness, like Polishness, is an ethnoreligious category that is perceived by many Poles on the right as the polar opposite of the Polak-katolik (Krzemiński 1996, 2001).

As Jewishness is a symbol standing for a liberal, plural, civic, and secular Poland, Poland is said by the right to be ruled by "Jews"- by symbolic Jews-who must be neutralized. Poland is thus host to the curious phenomenon of anti-Semitism in a country virtually without Jews. ${ }^{8}$ But that very process is also at the source of philo-Semitism. For if ethnoreligious nationalists contend that "Jews" are contaminating the nation with their civic ideals, auguring a pernicious postnational, cosmopolitan world and must therefore be politically marginalized, according to proponents of a civic vision of the polity "Jews" must for the same reason be rescued, and Jewishness promoted. Hence liberal, leftist youth wear tshirts and brandish posters in protests against clerical nationalists, proudly claiming "We are Jews."

Since the 1990s, there has been phenomenal rise of interest in Jewish culture and Judaism. There are currently at least 16 annual festivals related to Jewish culture and/or Judaism, held in

\footnotetext{
${ }^{6}$ The American case is the paradigmatic example of ideologically defined national identity, where "being" American means to support a specific set of values and practices, and therefore where it is possible to be "un-American." See Lipset (1990) for an analysis of this mechanism.

${ }^{7}$ Even though its ideologues insist on its primordial character, the ethnic nation is also a social construction. Whereas the civic nation is conceived as a construct, the ethnic nation is conceived as a given. This is not, however, what I am underlining here. Rather, I am pointing out the ideological criteria used by the right in determining one's Polishness (or lack thereof) and the tension such criteria entail for the (ideally) ethnically defined nation. For discussions of the principles behind ethnic and civic nationalism, see Brubaker (1992), Schnapper (1998), Yack (1996), Nielsen (1997), and Zubrzycki (2001).

${ }^{8}$ It is very difficult to establish the exact number of Jews in Poland. Estimates vary greatly, ranging from 1,055 (Polish Census 2002) to 40,000 (American Jewish Year Book, 2003, 2004). This wide variation is due to how Jewishness is determined (self-declaration in the Census, formal membership in Jewish organizations, or ancestry), but also because Jewish communities have witnessed a cultural, religious, and institutional renaissance since the fall of communism. According to Piotr Kadlčik, president of the Union of Jewish communities in Poland, there are between 4,000 and 6,000 "registered Jews" (people with formal ties to one or more Jewish organizations) and between 20,000 and 25,000 Polish citizens of Jewish descent who do not maintain a formal connection to these institutions (personal interview, May 2004). Similar estimates were given by Poland's Chief Rabbi, Michael Schudrich, in 2007 (American Jewish Committee, 2007).
} 
13 Polish cities, most of them initiated in the 1990s and 2000s (Gruber 2002; Jewish Heritage Travel 2010). The dramatic growth in size and popularity of Kraków's festival is telling: founded in 1988, the Festival was once a modest two-day local affair that offered a restricted program, with limited appeal for the public at large. It is now a major national and international event that, under the patronage of the President of the Republic of Poland, lasts 11 days and is attended by some 25,000 people from Poland and abroad. Its final open-air concert, "Szalom on Szeroka Street," is free to the public and televised live on nationwide television (audio recording of interview with Janusz Makuch, co-Founder and Director of Kraków's Festival of Jewish Culture; Festiwal Kultury Zydowskiej w Krakowie 2011). The renewed popularity of klezmer music, the dramatic proliferation of Judaica bookstores and Jewish cuisine restaurants (most of them non-Kosher), the governmental sponsorship of "virtual shtetls," the emergence of Jewish studies programs at multiple universities, the opening of new museums and memorials, the routinization of artists' and public intellectuals' artistic engagements with Poland's Jewish past and Polish-Jewish relations more broadly, as well as the growing number of conversions to Judaism are other indicators of this phenomenon.

Non-Jewish Poles' goal to revive Jewishness through memory work (cf. Irwin-Zarecka 1989; Nora 1989) and cultural activism does not merely mark the folklorization of Jews and things Jewish (cf. Lehrer 2003), nor is it simply Poles' outlet for the working through of cultural trauma (Alexander et al. 2004) or their expression and expiation of guilt (Forecki 2010; Olick 2007). Rather, these efforts and the support of Judaism's revival in Poland are part of a broader attempt to soften and stretch the symbolic boundaries of the nation that the right wants to harden and shrink with a conservative, nationalist version of Catholicism as its primary tool. It is a means through which the pluralistic society that was eradicated during World War II is symbolically reclaimed, and through which dominant Catholic tradition is neutralized. Polish philo-Semitism, I show in detail elsewhere, is in large degree an attempt by various social actors, political groups, and state agencies to build and promote a plural society in and against an ethnically and religiously homogenous nation-state. Although the diversity that characterized Poland for most of its history is unlikely to return, civic nationalists see the recognition of its legacy as a tool not only to build an open society, but also to mark Poland as a polity that meets the standards of an internationally normative model of nationhood that values and encourages multiculturalism and pluralism of all stripes. Since ideological pluralism "does not count" in the eyes of ethno-Catholic nationalists as a legitimate counterweight to "objective homogeneity," many activists create visible, countable, "objective" alternatives by reviving Jewish culture, supporting the revival of Jewish communities, promoting knowledge about Poland's Jewish past and present, and even introducing Jewish symbols in the public sphere. Since the mid-2000s, for example, a giant menorah is lit in Warsaw on the first night of Hanukkah by the Chief Rabbi of Poland accompanied by city officials (Virtual Shtetl 2010). Important and visible museums related to Jewish history and Jewish life have also altered the museological landscape of Poland: Kraków's Galicja Jewish Museum, for example, was founded in 2003 to provide a "contemporary look at the Jewish past in Poland" (Galicja Jewish Museum 2003), and Schindler's Factory Museum opened in 2010 to provide a dynamic and complex picture of everyday life for non-Jewish and Jewish Poles in Kraków before and during World War II. The most ambitious project, Warsaw's Museum of the History of Polish Jews, has been in the works for a decade and plans its grand opening in 2013, an event President Obama has promised to attend with his daughters (http://www.jewishmuseum.org.pl/en/cms/home-page/.) Dozens of other smaller museums and memorials have also mushroomed throughout Poland.

Bringing back secular Jewish culture and supporting the revival of Judaism is a way to plausibly argue that Polishness is not only about Catholic practices and folklore; that Polishness is also about broad universalist values that have shaped a long tradition of "religious tolerance," which led to the flourishing of Jewish religious and communal life, prosperous Jewish towns, and peaceful shtetls. This discursive strategy does not, however, "whitewash" history to erase 
traces of anti-Semitism. Many of the non-Jewish activists, artists, volunteers, and consumers or Jewish-centered events and initiatives whom I have interviewed told me that "revelations" of violent crimes committed against Jews by ethnic Poles (Gross 2000, 2006) were often at the source of their interest in Jewish history and culture. Reviving religious tradition and actively supporting Jewish communities' revival of Judaism is a way to give concrete shape to seemingly amorphous ideological pluralism in order to trump the "hard" demographic "facts" of Poland's "un-natural" ethnoreligious homogeneity; a way to neutralize Catholicism as a religious tradition that has political traction.

\section{Resurrecting Catholicism to Tame Pluralism in Québec}

Once nicknamed "the priest-ridden province," during the 1960s' Quiet Revolution Québec dramatically rid itself of Catholicism, amputating what a new generation of social activists and political figures had come to see as a gangrenous limb preventing the healthy development of the nation. The building of a modern provincial welfare state and the secularization of social services such as education, healthcare, and welfare was accompanied by the profound disenchantment of society and an extremely rapid de-institutionalization: ${ }^{9}$ the 1960 s are characterized by a stringent critique of the Church, a drastic decline in religious practice, and even a significant incidence of clergy renouncing their vows to renter secular society. In Montréal, for example, participation in Sunday Mass dropped by almost two-thirds, from 88 percent in 1957 to 30 percent in 1971 (Christiano 2007:31; Hamelin 1984:277). Within a decade or so, churches that were previously thronged with people several days a week now sat empty. Some were later bulldozed; others were sold to developers who transformed them into condominiums or hotels; others remained to be transformed from sites of ritual practice into sites of "cultural heritage" (Zubrzycki 2012). These transformations were occurring just when the Church itself, during the Second Vatican Council, was critically reassessing its role in modern society, which facilitated its retreat from the political and social spheres (Baum 1991; Lemieux 2006; Routhier 1997; Seljak 1996).

As religious practice tumbled, so did fertility. In 1959, on the eve of the Quiet Revolution, Québec had the highest birth rate of all the provinces in Canada. By 1972 it had the lowest (Christiano 2007:34-35). While in the late 1950s the typical French Canadian woman in Québec had on average four children, by the early 1970s fertility had dropped by half to 2.09 children per woman, below the 2.1 standard required for population replacement (Christiano 2007:34). When many thought it could not get lower, in 1986, the rate hit a record low at 1.4 children per woman, what demographers call "low-low fertility," creating a wave of insecurity about the future of the nation, a nation increasingly described in the media and political discourse as "endangered" (en voie de disparition) (Zubrzycki 2012). While decreases in fertility are common in the Western world in that period, the extent and rapidity of this drop is unusual, and the panic it created was at the source of immigration policies that not only favored, but actually actively encouraged the immigration of francophone populations to Québec in order to maintain the delicate linguistic balance of the province. ${ }^{10}$ That initiative, however, brought religion "back on the table," as many of those recent immigrants are significantly more religious than the Québécois, and most are also

\footnotetext{
${ }^{9}$ I am using Riesebrodt's conceptual framework here, distinguishing secularization (the separation of social and religious institutions), disenchantment (rationalization of consciousness), and deinstitutionalization (transformation of religious institutions, specifically the shrinking membership and the declining participation in religious practice) (2010:174-81).

${ }^{10}$ Québec has control over immigration to its territory and regards prior knowledge of French an important factor in reviewing applications. Approximately 40 percent of immigrants settling in Québec therefore know French (about 25 percent know only French, and about 15 percent know both French and English; 20 percent know English only and 40 percent know neither French nor English) (http://www.micc.gouv.qc.ca/fr/recherches-statistiques/index.html).
} 
non-Christian. ${ }^{11}$ The secularization of Québec, then, is partially responsible for the creation of today's revitalized religious landscape.

Many today thus often perceive religion as either an atavistic residue of the past surviving at the margins of society, or imported from "outside" by recent waves of immigrants. This became apparent in the debates over the religious practices of cultural minorities, which were at the center of public life from 2006 to 2008. That debate over "Reasonable Accommodations" was ignited when several incidents involving religious minorities and Québec's secular majority made provincial headlines. In one high-profile episode, fathers attending their children's swimming exam were asked to leave the pool area because their presence caused discomfort to Muslim women enrolled in a swimming class at the same moment. In another case, frosted-glass windows were installed at a Montréal YMCA at the request—and expense-of ultra-Orthodox Jews who wished to protect young boys walking to their neighborhood yeshiva from temptations posed by the sight of women exercising at the gym.

These are only two examples from a long list of incidents that punctuated the last decade, incidents that were widely reported in Québec media and that were often closer to rumors and half-truths than actual, "factual" events. ${ }^{12}$ Since many requests are accommodated on an ad hoc basis (between student, parents, and teacher; employee and employer; and so forth) and thus never become a legal or public issue, there exists no clear and full picture of accommodation practices. According to the Bouchard-Taylor Commission's report, however, a significant number of requests for accommodation are made by practicing Catholics, Jehovah's Witnesses, and Seventh Day Adventists who seek adjustments to their work schedule, for example. That the cases reported in the media and that captured public attention were those involving non-Christian groups, primarily Muslims, Sikhs, and ultra-Orthodox Jews, is telling.

In most cases brought to public attention, what prompted vocal opposition was not so much religious minorities' requests for special permissions or for the loosening of certain rules at specific moments (such as parking regulations or the erection of temporary religious structures) or their request to curtail widely accepted practices of the host society (such as co-ed swimming pools) - but rather the perception of public institutions' overaccommodation of what were not considered by most to be "reasonable" expectations. How much should a host society, itself a minority within Canada, accommodate minorities living amidst it without "losing itself"? The debate about the increasing visibility of religion in the public sphere thus quickly morphed into a debate about the very identity of Québec.

The media widely commented on what it had named "La crise des accommodements," and the "crisis" entered the social and political spheres. Mario Dumont, leader of a conservative political party, decried in a clever neologism that the Québécois were afflicted by "aplaventrisme"-from à plat ventre, "flat on your belly." In a widely disseminated open letter, he wrote that they suffered from "spinelessness" since they passively acquiesced to the requests of those who should be the ones to adapt, of those who "when in Rome, should do as the Romans do." Around the same time, however, André Boisclair, then leader of the left-leaning and separatist Parti Québécois, noted that no one had ever requested the removal of the crucifix at the National Assembly, even though, in his personal opinion, that religious symbol had no place at such an institution.

\footnotetext{
${ }^{11}$ Haitians, who are francophone and primarily Catholic, have been relatively successfully integrated into Québec society, and have not been the object (or subjects) of debates during the investigation on reasonable accommodation, which I discuss next.

${ }^{12}$ Detailed accounts of those cases and dozens more — of events themselves and how they were (mis)reported in the press - can be found in two chapters of the Bouchard-Taylor Commission's final report (Bouchard and Taylor 2008b: 45-76). Social scientific analyses can be found in Stoker (2003, 2007), Bock-Coté (2007), Gaudreault-Desbiens (2009), and Koussens (2009). For journalistic accounts and essays, see Geadah (2007), Bégin (2007), Baril (2007), Thompson (2007), Dufour and Heinrich (2008), and Potvin (2008). On secularism in Québec, see Milot (2005).
} 
What became evident, during the months of the Commission's public consultation and through its lively public debate, is that Québécois remain "Catholic" in their secularism. By that I mean that their secularism is defined and articulated against that religion; they are "recovering Catholics." The story they tell about themselves, since the Quiet Revolution, is one about their overcoming religion. As a result of that specific historical trajectory and the cultural valence of its narrative, they often tend to view religion in general with great suspicion. Yet, despite relegating Catholicism (as religion) largely to the past, Catholicism as religious tradition nevertheless continues to inform "who they are" in a broad cultural way.

This was evident in Québec Premier Jean Charest's first response to the recommendation of the Bouchard-Taylor Commission's report to remove some problematic remnants of Catholicism in the public sphere, including a large crucifix over the seat of the speaker at the National Assembly in Québec City. In their report, Bouchard and Taylor stated that "[i]n keeping with the notion of the separation of Church and State, ... the crucifix must be removed from the wall of the National Assembly" (2008b:60). That crucifix was installed there by Premier Maurice Duplessis ${ }^{13}$ in 1936, and suggests, according to the Commissioners, "a special proximity between the legislative power and the majority's religion." "It seems preferable," they thus noted, "that the very site where elected representatives deliberate and legislate not be identified with a specific religion. The National Assembly is the assembly of the entire population of Québec" (my translation, Bouchard and Taylor 2008a:152-53). Just hours after the report was officially made public, Premier Charest proposed instead a motion to retain the said crucifix as symbolic of Québec's religious heritage and culture, its collective memory; not, as Charest insisted at the National Assembly, as a symbol of the religious beliefs of individual deputies. Though the nation is not primordially constituted and certainly changes, Premier Charest argued, it remains historically and culturally construed, and that tradition has enduring power. By voting on that specific motion, the Québec legislative assembly was hardening the symbolic contours of the nation, affirming that together with French, Catholicism, albeit in its patrimonial form, is key to "who we are." This move, however, was far from being widely accepted. It was harshly criticized by politicians, public intellectuals, and citizens who aim at legally establishing secularism via Bill 94, currently under study at the National Assembly.

While some argue that Québec is a former Catholic society and that Catholicism remains part of "who we were" and thus "who we are as a society," others insist on the heritage of the Quiet Revolution and its forceful rupture with religion. They thus are for the official establishment of a "truly secular" society in which religious individuals and groups have no special rights under the law. For both groups, then, the reasonable accommodation of cultural minorities' religious practices was seen as a problematic practice "for the nation," albeit for different reasons. Bouchard and Taylor (2008a), in their report, proposed a third way: "open secularism," a system whereby institutions and their representatives maintain religious neutrality, but in which ordinary citizens have the right to practice their religion and request special accommodations in so far as these do not create undue hardship for institutions. That middle-ground position was rejected by both the federalist right and the separatist left, and by both the government and the opposition. The commissioners' recommendations were thus for the most part ignored and the report soon forgotten.

Premier Charest's motion to retain the crucifix at the National Assembly as symbolic of a religious tradition that made us "who we are," however, was more than a political move in a

\footnotetext{
${ }^{13}$ Maurice Duplessis (1890-1959) ruled the Province of Québec for almost a quarter of a century. His political tenure was characterized by rabid corruption and quid pro quo relationships with the Catholic Church and big business. His death triggered a movement for the wholesale rejection of the status quo. Thus began a decade of profound transformations that pulled out Québec not only from Duplessis' era of so-called Great Darkness, but also marked Québec's forceful entry into modernity. On the Quiet Revolution as historical rupture, myth, and identity marker, see Gagnon and Sarra-Bournet (1997) and Létourneau (1997).
} 
specific debate. The motion, approved by the legislative assembly, was consistent with policies and government programs that invest, since the 1990s, in "religious patrimony." The government of Québec indeed allocates financial aid as well as provides expertise to preserve and maintain any elements of religious buildings and sites (structures, materials, furniture, artifacts and artwork, landscape, and monuments) recognized as having "patrimonial value." So far the government has spent 210 million dollars in restoring this "religious patrimony." As stated on the website of the Conseil du patrimoine religieux du Québec:

For the Conseil, Québec religious heritage appears to be a founding heritage, if we take into consideration that religious preoccupations and religious buildings have been present since the origin of Québec society. Among our entire cultural heritage, it is the most universal, the most diversified, and the richest. It is also the most visible and the most spread out over the territory. It represents a major expression of the culture of Québec and an important element of our identity, expressing the social, ethical and philosophical values of our society. (Religious Heritage Counsel 2007a)

Religious tradition is therefore enshrined as a collective "good" and now sacralized through the notion of cultural patrimony. A report published in June 2006 by the Commission de la culture was tellingly entitled "Croire au patrimoine religieux" (Secrétariat des commissions de l'Assemblée nationale du Québec [2006] "Believing in Religious Patrimony"; emphasis in original). What matters here is not religious belief, but belief in religious tradition. In an attempt to inform and educate a public that no longer believes or practices, the state has also put forth "awareness campaigns," posting large banners on religious sites whose preservation is funded by the state, with the slogan "Our cultural patrimony, it's sacred!" The state, in this reframing, funds (and sacralizes) not religion per se, but a religious tradition transformed into the broader and putatively neutral notion of cultural patrimony. ${ }^{14}$ It is through "cultural patrimony" and "culture" more broadly, then, that many secular and even atheist Québécois remain "Catholic" and continue to perceive members of non-Catholic groups as "other."

Québec may well be secular, but religious tradition survives either in defining a collective "us, cultural Catholics" against a certain "non-Catholic them," or by informing an "irreligious us" against a "religious them." The commissioners' recommendation to remove the crucifix at the National Assembly, along with earlier requests by left-leaning separatist politicians, however, suggests an awareness of the tension between a secular Québécois identity and its Catholic French Canadian origins. Even as the crucifix remains as part of Québec's religious tradition, the Québécois' relationship to religion per se is defined by a profound ambivalence, as can be seen in the debates over reasonable accommodation and their aftermath.

\section{Religion, Religious Tradition, Secularization}

The comparison of the two cases demonstrates two distinct ways in which "religion" and "religious tradition" interact.

In Québec, it is recent demographic diversity and religious pluralism that impels the provincial government and political actors to resurrect Catholicism-now reframed as a putatively neutral "cultural" heritage- to serve as a counterweight to a threatening religious mosaic, thereby ensuring the primacy of secular francophone Québécois within Québec. If Catholicism as a religion proper is viewed with deep suspicion, Catholicism as religious tradition, to use Riesebrodt's useful

\footnotetext{
${ }^{14}$ The state does not solely fund the restoration and preservation of Catholic sites, and the website of the Conseil is careful, in its visuals, to showcase religious patrimony of other religious communities. By reason of the sheer number of Catholic sites in Québec, however, the latter constitute the overwhelming majority of projects funded (Religious Heritage Counsel 2007b).
} 
distinction, is embraced by key state institutions. This move by the state to redefine Catholicism as cultural patrimony is meant to redefine and harden the symbolic boundaries of the nation that many argue have been stretched to breaking by the overaccommodation of the religious practices of cultural minorities. Thus the "host" society's religious tradition is applied to counter, and tame, the religion(s) of its "guests."

In Poland, the power of the Catholic Church and the right is combatted by reaching back to the past and resurrecting the "Jew," Poland's traditional ethnoreligious Other. Philo-semitism is at least in part an attempt by center-left political and social groups to render visible an ideologically plural society, even in an ethnically and religiously homogenous nation-state. In this case, then, Jewish religious tradition and religion are catalyzed by progressive political actors to crack the hegemonic force of Polish-Catholic religious tradition.

In both cases, collective identity is at stake. In the Polish case, the revival of Jewish religious tradition and the support of Judaism act as a counterweight to Catholicism as the dominant religious tradition, serve to build pluralism by giving flesh to an abstract ideological form, thereby stretching the symbolic boundaries of the nation. In the case of Québec, Catholicism as religious tradition is meant to offer a counterweight to immigrants' religions, serves to tame religious pluralism, and shrink the symbolic boundaries of the nation. Riesebrodt's conceptual distinction between religion and religious tradition thus offers a useful framework to disentangle various phenomena and processes at work.

Riesebrodt's distinctions between secularization, disenchantment, and de-institutionalization are also helpful to offer nuanced interpretations of related processes. They allow us, for example, to make sense of how Poles can, on one hand, remain religious both in terms of their beliefs and practices yet be very critical of the Church. They also allow us to see how social actors who oppose the centrality of an ethnoreligious vision of Polishness do so by advocating secularity-the neutrality of state institutions in matters of religion-while simultaneously supporting the revival of Judaism and the promotion of Jewish culture in the public sphere. They support and approve the revival of a minority religious tradition and religion to neutralize the efforts of supporters of the dominant religious tradition, preventing them from highjacking the definition of the nation and monopolizing the political field.

Riesebrodt's framework is likewise helpful in making sense of the Québécois' complex relationship to religion and religious tradition: Québec's social and political institutions have been secularized; its host population is largely disenchanted and membership in religious institutions is low. But religious tradition, especially in its material culture and its rituals, remains available for activation toward political goals when the need to strengthen their position vis-à-vis religious Others arises.

While many before him have argued that a distinction between the religious and the sacred should be maintained, Riesebrodt's further distinctions are helpful to identify the different registers at which the "religious" is evoked, used, abused, and for what purposes and to what effect. Despite what Durkheim would claim, form is not all; content does matter. Football is not the same as "properly religious" practices, though it may be productive to think about sports or other massevents in relation to religion proper. Distinguishing between the religious and the sacred is, however, empirically more challenging when studying cases where religious tradition becomes a broad category of identification that is politicized and sacralized as such, and where religion, religious tradition, and national identity are thoroughly entangled. As important as Riesebrodt's distinction between religion and religious tradition is, his own theorizing is focused on "religion" proper. To avoid conflating the religious and the sacred, and avoid equating desacralization with secularization (and sacralization with desecularization), we need to further develop and specify the concept of religious tradition. In my own work on the various imbrications of religion and politics, I proposed that we pay attention to the process through which, in specific cases, religious tradition comes to provide the materials for political identity in the first place. This is quite 
different from the process when political symbols of the group are sacralized, the paradigmatic case of Durkheimian civil religion. There is a significant difference between a religious tradition that becomes a material and symbolic resource for identity building and is sacralized as a marker of the nation, and the straightforward (and usual) sacralization of political symbols of the nation.

For Poland and Québec, as for other cases where national identity has been historically constructed via religious tradition and institutions, the meanings of secularization and religious revitalization are especially complex. Without the distinction between religion and religious tradition-and between various dimensions of what is lumped as "secularization"-arguments from Catholic elites in today's Poland to de-politicize Catholicism qua religious tradition might be taken as an attempt to disenchant Polish society, whereas those groups actually understand that process as one of religious revitalization since what they advocate is a return to religion proper, focusing on the deepening of faith and its active internalization by believers. Without the distinction, we might look at Québec's government promotion of Catholic heritage as an attempt to re-enchant, when it is actually a means to counteract the increasing role of religion in the public sphere.

Riesebrodt's conceptual distinction between religion and religious tradition is analytically powerful, yet in his own work, religious tradition mostly serves to give precision to a definition of religion proper. This article, by contrast, attended to the meanings and uses of religious tradition to compare two empirical cases where "religion" and "religious tradition" are not continuous, wherein one is an expansion of the other, but are rather counterposed in the service of a particular vision of the nation.

\section{REFERENCES}

Alexander, Jeffrey C., Ron Eyerman, Bernhard Giesen, Neil J. Smelser, and Piotr Sztompka (eds.). 2004. Cultural trauma and collective identity. Berkeley, CA: University of California Press.

American Jewish Committee. 2003. American Jewish year book. New York.

2004. American Jewish year book. New York.

- 2007. American Jewish year book. New York.

Balthazar, Louis. 1986. Bilan du nationalisme au Québec [The state of nationalism in Québec]. Montréal, Canada: L'Hexagone.

Baril, Daniel. 2007. Les accommodements religieux pavent la voie à l'intégrisme [Religious accommodations lead to religious fundamentalism]. Ethique Publique 9(1):174-81.

Baum, Gregory. 1991. The church in Quebec. Outremont, Canada: Novalis.

Bégin, Paul. 2007. Laicité et accommodements raisonnables [Secularism and reasonable accommodations]. Ethique Publique 9(1):158-65.

Bock-Côté, Mathieu. 2007. Behind secularism, the nation: Looking back at the controversy of reasonable accommodations and the crisis of Québécois multiculturalism. GLOBE: Revue internationale d'études Québécoises 10(2):95-113.

Bouchard, Gérard. 1999. La nation québécoise au futur et au passé [The Québécois nation, past and future]. Montréal, Canada: VLB éditeur.

Bouchard, Gérard, and Charles Taylor. 2008a. Building the future: A time for reconciliation. Montréal: Commission de consultation sur les pratiques d'accomodement reliées aux différences culturelles [Consultation Commission on Accommodation Practices Related to Cultural Differences].

- 2008b. Fonder l'avenir. Le temps de la conciliation [Building the future: A time for reconciliation]. Montréal: Gouvernement du Québec.

Breton, Raymond. 1988. From ethnic to civic nationalism: English Canada and Quebec. Ethnic and Racial Studies 11(1):85-102.

Brubaker, Rogers. 1992. Citizenship and nationhood in France and Germany. Cambridge, MA: Harvard University Press. Centrum Badania Opinii Spolecznej [Public Opinion Research Center]. 2009. Wiara i religiJność Polaków 20 lat po rozpocięciu przemian ustrójowych [Poles' faith and religiosity 20 years after the beginning of the systemic transformations]. Warsaw: CBOS.

Christiano, Kevin. 2007. The trajectory of Catholicism in twentieth-century Quebec. In The church confronts modernity: Catholicism since 1950 in the United States, Ireland, and Quebec, edited by Leslie Woodcock Tentler, pp. 21-61. Washington, DC: The Catholic University of American Press.

Dufour, Valérie, and Jeff Heinrich. 2008. Circus québecus: Sous le chapiteau de la commission Bouchard-Taylor [Circus québecus: Under the tent of the Bouchard-Taylor Commission]. Montréal: Les Éditions du Boréal. 
Dumont, Fernand. 1986. Histoire du catholicisme québécois, histoire d'une société [History of Québec Catholicism, history of a society]. Recherches Sociographiques 27:115-25.

_. 1993. Genèse de la société québécoise [Genesis of Québec society]. Montréal, Canada: Boréal.

Eid, Nadia F. 1978. Le clergé et le pouvoir politique au Québec: Une analyse de l'idéologie ultramontaine au milieu du XIXème siècle [The clergy and political power in Quebec: Analysis of ultramontane ideology in the mid 19th century]. Montréal: Hurtubise.

Ferretti, Lucia. 1999. Brève histoire de l'église catholique au Québec [Concise history of the Catholic Church in Québec]. Montréal, Canada: Boréal.

Festiwal Kultury Żydowskiej w Krakowie (FKZK) [Festival of Jewish Culture in Kraków]. 2011. 21st Jewish Culture Festival in Kraków, Poland. Report. Available at http://www.jewishfestival.pl/reports,18,p,en.html, accessed January 10, 2012.

Forecki, Piotr. 2010. Od shoah do strachu: Spory o polsko-żydowska przeszłość i pamięc $w$ debatach publicznych [From Shoah to fear: Contested issues about Polish-Jewish past and memory in public debates]. Poznań, Poland: Wydawnictwo Poznańskie.

Frenette, Yves. 1998. Brève histoire des Canadiens français [Concise history of the French Canadians]. Montréal, Canada: Boréal.

Gagnon, Alain and Michel Sarra-Bournet (eds.). 1997. Duplessis: Entre la grande noirceur et la société libérale [Duplessis: Between the great darkness and liberal society]. Montréal, Canada: Editions Québec-Amérique.

Gaudreault-DesBiens, Jean-Francois. 2009. Religious challenges to the secularized identity of an insecure polity: A tentative sociology of Québec's reasonable accommodation debate. In Legal practice and cultural diversity, edited by Ralph Grillo, Roger Ballard, Alessandro Ferrari, André J. Hoekema, Marcel Maussen, and Prakash Shah, pp. 151-76. Surrey, UK: Ashgate.

Geadah, Yolande. 2007. Accomodements raisonnables: Droit à la différence et non différence des droits [Reasonable accommodations: The legal right to difference, but not different rights]. Montréal, Canada: VLB.

Gross, Jan Tomasz. 2000. Sasiedzi [Neighbors]. Sejny, Poland: Pogranicze.

- 2006. Fear: Anti-semitism in Poland after the Auschwitz. New York: Random House.

Gruber, Ruth Ellen. 2002. Virtually Jewish: Reinventing Jewish culture in Europe. Los Angeles, CA: University of California Press

Hamelin, Jean. 1984. Histoire du catholicisme québécois: Le XXe siècle, Vol. 2 (De 1940 à nos jours) [History of Québec Catholicism, Vol. 2 (From 1940 to this day)]. Montréal, Cananda: Boréal.

Irwin-Zarecka, Iwona. 1989. Neutralizing memory: The Jew in contemporary Poland. New Brunswick, NJ: Transaction Publishers

Jewish Heritage Travel. 2010. Jewish culture festivals in Europe. Available at http://jewish-heritagetravel.blogspot.com/2010/02/jewish-culturemusicetc-festivals-2010.html, accessed January 10, 2011

Kłoczowski, Jerzy. 2000. History of Polish Christianity. Cambridge, UK: Cambridge University Press.

Koussens, David. 2009. Neutrality of the state and regulation of religious symbols in schools in Québec and France. Social Compass 56(2):202-13.

Krzemiński, Ireneusz (ed.) 1996. Czy Polacy sq antysemitami? Wyniki badania sondażowego [Are Poles anti-Semites? Results from survey research]. Warszawa: Oficyna Naukowa.

—. 2001. Polacy i Żydzi: Wizja wzajemnych stosunków, tożsamość narodowa i antysemityzm [Poles and Jews: Vision of inter-relations, national identity and anti-Semitism]. In Trudne sasiedztwa. Z sociologii konfliktów narodowościowych [Difficult neighbors: A sociology of national conflicts], edited by Aleksandra Kania, pp. 171-200. Warsaw: Wydawn Naukowe Scholar.

Lamont, Michèle and Christopher A. Bail. 2005. Les frontières de la reconnaissance. Les catégories internes et externes de l'identité collective [The boundaries of recognition internal and external categories]. Revue Européenne des Migrations Internationales 21(2):61-90.

Lehrer, Erica. 2003. Repopulating Jewish Poland, in wood. Polin: Studies in Polish Jewry 16:335-55.

Lemieux, Raymond. 2006. Catholicisme et fonction identitaire: Du 'Canada français' au Québec contemporain [Catholicism and identity: From "French Canada" to contemporary Québec]. In Le Canada français: Son temps, sa nature, son heritage [French Canada: It's time, nature, and legacy], edited by G. Gagné, pp. 29-41. Hastings-on-Hudson, NY: Nota Bene.

Létourneau, Jocelyn. 1997. La Révolution tranquille, catégorie identitaire du Québec contemporain [The quiet revolution, identity category in contemporary Québec]. In Duplessis: Entre la grande noirceur et la société libérale [Duplessis: Between the great darkness and liberal society], edited by Alain- G. Gagnon and Michel Sarra-Bournet, pp. 95-108. Montréal, Canada: Québec/Amérique.

Lincoln, Bruce. 2003. Holy terrors: Thinking about religion after September 11. Chicago, IL: University of Chicago Press.

Lipset, Seymour Martin. 1990. Continental divide: The values and institutions of the United States and Canada. Washington, DC: Canadian-American Committee

Michowicz, Waldemar. 1988. Problemy mniejszości narodowych [National minorities' problems]. In Polska odrodzona, 1918-1939 [Poland reborn, 1918-1939], edited by Jerzy Tomicki, pp. 285-321. Warsaw: Wiedza Powszechna. 
Milot, Micheline. 2005. Les principes de laïcité politique au Québec et au Canada [The principles of political secularism in Québec and Canada]. Bulletin d'Histoire Politique 13(3):13-27.

Morawska, Ewa. 1984. Civil religion vs. state power in Poland. Society 21(4):29-34.

Nielsen, Kai. 1997. Cultural nationalism, neither ethnic nor civic. Philosophical Forum: A Quarterly 28(1-2):42-52.

Nora, Pierre. 1989. Between memory and history: Les lieux de memoire. Représentations 26(Special Issue):7-24.

Olick, Jeffrey K. 2007. The politics of regret: On collective memory and historical responsibility. Oxon, UK: Routledge.

Polish Census Data. 2002. http://www.stat.gov.pl/gus/8185_PLK_HTML.htm, accessed March 11, 2012.

Potvin, Maryse. 2008. Crise des accomodements raisonnables: une fiction médiatique? [The reasonable accommodation crisis, a media invention?] Montréal, Canada: Athena.

Religious Heritage Counsel of Quebec. 2007a. Preservation principles. Available at http://www.patrimoinereligieux.qc.ca/en/aidefinanciere/principes.php, accessed October 15, 2009.

—. 2007b. Mission. Available at http://www.patrimoine-religieux.qc.ca/en/organisme/mission.php, accessed January 10, 2012.

Riesebrodt, Martin. 1990. Pious passion: The emergence of modern fundamentalism in the United States and Iran. Berkeley, CA: University of California Press.

- 2010. The promise of salvation: A theory of religion. Chicago, IL: University of Chicago Press.

Routhier, Gilles. 1997. L'église canadienne et vatican II [The Canadian church and Vatican II]. Saint-Laurent, Québec: Fides.

Schnapper, Dominique. 1998. Community of citizens: On the modern idea of nationality. New York: Transaction Publishers.

Secrétariat des commissions de l'Assemblée nationale du Québec [Office of the commissions of the National Assembly of Québec]. 2006. Croire au patrimoine religieux du Québec: Mandat d'initiative entrepris par la commission de la culture. Rapport, Juin 2006 [Believing in Québec's religious heritage: The Commission of Culture's Mandate]. Québec: Assemblée nationale du Québec.

Seljak, David. 1996. Why the Quiet Revolution was 'quiet': The Catholic Church's reaction to the secularization of nationalism in Quebec after 1960. Historical Studies 62(1):109-24.

Smith, Jonathan Z. 1998. Religion, religions, religious. In Critical terms for religious studies, edited by Mark C. Taylor, pp. 269-84. Chicago, IL: University of Chicago Press.

Stoker, Valerie. 2003. Drawing the line: Hasidic Jews, eruvim, and the public space of Outremont, Québec. History of Religions 43(1):18-49.

- 2007. Zero tolerance? Sikh swords, school safety, and secularism in Québec. Journal of the American Academy of Religion 75(4):814-39.

Taylor, Charles. 2007. A secular age. Cambridge, MA: Belknap Press.

Thériault, Joseph Yvon. 1999. La nation francophone d'Amérique: Canadiens, Canadiens français, Québécois [The Francophone nation of America: Canadians, French Canadians, Québécois]. In Dislocation et permanence: L'invention $d u$ Canada au quotidian [Dislocation and permanence: The daily invention of Canada], edited by Caroline Andrew, pp. 111-37. Ottawa: Ottawa University Press.

Thompson, Bernard. 2007. Le syndrome Hérouxville ou les accomodements raisonnables [The Hérouville syndrome, or reasonable accommodations]. Highland Park, NJ: Momentum.

Tomaszewski, Jerzy. 1993. The national question in Poland in the twentieth century. In The national question in Europe in historical context, edited by Mikuláš Teich and Roy Porter, pp. 293-316. Cambridge, MA: Cambridge University Press.

Virtual Shtetl. 2010. The first Hannukah Menora to kindle in Warsaw. Available at http://www.sztetl.org. pl/en/cms/news/1018,the-first-hannukah-menorah-to-kindle-in-warsaw/, accessed December 19, 2011.

Yack, Bernard. 1996. The myth of the civic nation. Critical Review 10(2):193-211.

Zubrzycki, Geneviève. 2001. We, the Polish nation: Ethnic and civic visions of nationhood in post-communist constitutional debates. Theory and Society 30(5):629-69.

2004. The broken monolith: The Catholic Church and the "war of the crosses at Auschwitz" (1998-99). In Nation and religion: An unfinished history, edited by Michael Geyer and Hartmut Lehmann, pp. 176-204. Göttingen, Germany: Wallstein-Verlag.

- 2006. The crosses of Auschwitz: Nationalism and religion in post-communist Poland. Chicago, IL: University of Chicago Press.

2010. What is pluralism in a "monocultural" society? Considerations from post-communist Poland. In After pluralism: Re-imagining models of interreligious engagement, edited by Courtney Bender and Pamela E. Klassen, pp. 277-95. New York: Columbia University Press.

- 2011. History and the national sensorium: Making sense of Polish mythology. Qualitative Sociology 34(1):21-57.

—. In press. Negotiating pluralism in Québec: Identity, religion and secularism in the debates over "reasonable accommodation." In Religion at the edge: Toward a new sociology of religion, edited by Courtney Bender, Wendy Cadge, Peggy Levitt, and David Smilde. New York: Oxford University Press. 